\title{
Drug Rash with Eosinophilia and Systemic Symptoms (DRESS) Syndrome Concurrent with Cytomegalovirus Infection: A Case Report
}

\author{
Eozinofili ve Sistemik Semptomların Eşlik Ettiği İlaç Döküntüsü \\ (DRESS) ile Eş Zamanlı Sitomegalovirus Enfeksiyonu: Bir Olgu \\ Sunumu
}

Zeliha HAYTOĞLU

Çukurova University, Faculty of Medicine, Department of Child Health and Diseases, General Children's Clinic, Adana, Turkey

\begin{abstract}
Drug rash with eosinophilia and systemic symptoms (DRESS) is characterized by a severe multiorgan hypersensitivity reaction that usually appears after a 3-6-week exposure to certain drugs, including anticonvulsants. Many reports have revealed that human herpesvirus $6(\mathrm{HHV}-6)$ reactivation contributes to the development of DRESS. In addition, recent articles have shown that reactivation of other herpesviruses such as human herpesvirus 7 (HHV-7), Epstein-Barr virus (EBV) and cytomegalovirus (CMV) might be also implicated in development of DRESS. Here we report development of the DRESS syndrome and concurrent presence of CMV viral load in a 2-year-old girl who was on phenytoin prophylaxis for febrile seizure
\end{abstract}

Key Words: Cytomegalovirus infection, Drug rash with eosinophilia and systemic symptoms, DRESS syndrome, Intravenous immunoglobulin

\begin{abstract}
ÖZET
Eozinofili ve sistemik semptomların eşlik ettiği ilaç döküntüsü (DRESS) genellikle antikonvülzanların dahil olduğu birtakım ilaçlara, 3-6 hafta maruz kaldıktan sonra görünen şiddetli çoklu organ aşırı duyarlılık reaksiyonu ile karakterizedir. Birçok çalışmada insan Herpes Virüs $6(\mathrm{HHV}-6)$ reaktivasyonunun DRESS gelişimine katkıda bulunduğu gösterilmiştir. Bununla birlikte yakın dönemdeki çalışmalarda diğer Herpes virüslerden, Herpes virüs 7 (HHV-7), Ebstein-Barr virüs (EBV) ve Sitomegalovirus (CMV) reaktivasyonunun DRESS gelişimiyle ilişkili olduğu gösterilmiştir. Burada febril konvülsiyon profilaksisi için fenitoin kullanmakta olan 2 yașında bir kız çocuğunda DRESS gelișimi ve eş zamanlı CMV viral yük varlı̆̆ı gösterilmiştir.
\end{abstract}

Anahtar Sözcükler: Sitomegalovirus enfeksiyonu, Eozinofili ve sistemik semptomların eşlik ettiği ilaç döküntüsü, DRESS sendromu, İntravenöz immunoglobulin

\section{INTRODUCTION}

Drug reaction with eosinophilia and systemic symptoms (DRESS) is a rare, potentially life-threatening, drug-induced hypersensitivity reaction that includes skin eruption, hematologic abnormalities (eosinophilia, atypical lymphocytosis), lymphadenopathy, and internal organ involvement (liver, kidney, lung) (13). The incidence of DRESS has been estimated to be between 1 in 1,000 and 1 in 10,000 drug exposures. It carries a mortality rate of $10-20 \%$, with most fatalities the result of liver failure (4).

To help clinicians in confirming the diagnosis of DRESS, the European Registry of Severe Cutaneous Adverse Reactions
(RegiSCAR) has devised a scoring system based upon the clinical features, extent of skin involvement, organ involvement, and clinical course (5). To meet the definition of DRESS, patients must have three of the four main RegiSCAR criteria: an acute rash, fever above $38^{\circ} \mathrm{C}$, lymphadenopathy at two sites, involvement of at least one internal organ, and abnormalities in lymphocyte and eosinophil counts. Additional criteria include hospitalization and a suspicion that the reaction is drug-related. The pathogenesis of DRESS remains incompletely understood. At least 44 drugs have been associated with DRESS. Antiepileptic agents are the most frequently reported causes (6). Reactivation of herpesvirus infection concurrent with drug hyper- 
sensitivity is considered specific to DRESS $(7,8)$. Reactivation of Cytomegalovirus (CMV) (9) or Epstein-Barr virus (EBV) (10) has also been reported. Withdrawal of the culprit drug and the use of corticosteroids constitute the mainstay of DRESS treatment. It is recommended to start systemic steroids when involvement of internal organs is manifest (6). We present a two-year-old girl with DRESS associated with phenytoin-induced CMV. We achieved the desired clinical response with intravenous immunoglobulin (IVIG) in our case.

\section{CASE REPORT}

A 2-year-old girl was admitted to our hospital with a history of high-grade fever $\left(39^{\circ} \mathrm{C}\right)$, sore throat, cough, and generalized rash for the previous ten days. Patient history revealed the use of phenytoin for the previous 4 weeks for prophylaxis of febrile seizures. Upon examination, the patient had bilateral cervical and inguinal lymph node enlargement and tender hepatomegaly along with facial edema and diffuse erythematous maculopapular rash without blistering and vesiculation (Figure 1). Laboratory values revealed an elevated leukocyte count $\left(22000 / \mathrm{mm}^{3}\right)$, eosonophilia (12\% of leukocytes), C-reactive protein $1.2 \mathrm{mg} /$ $\mathrm{dL}$, with an ESR of $30 \mathrm{~mm} / \mathrm{h}$. Elevated liver enzymes (ALT 140 UI/L, AST $100 \mathrm{UI} / \mathrm{L})$ and hypoalbuminemia $(2.1 \mathrm{~g} / \mathrm{dL})$ were detected. There was evidence of interstitial pneumonitis on the chest radiograph.

Imaging studies revealed hepatomegaly without features of hepatitis. Serology was negative for Hepatitis A, B, and C. Blood culture and antinuclear antibody were negative. During the course of the disorder, EBV IgM and IgG antibodies were negative while both CMV IgM and Ig $\mathrm{G}$ antibodies and CMV PCR were positive. According to the RegiSCAR Scoring System, our patient was diagnosed as "definite" DRESS. Because of the active CMV infection, we did not use corticosteroid treatment. We used $1 \mathrm{gr} / \mathrm{kg}$ IVIG on the first admission day. On the second day, the rash subsided and there was no fever. Elevated liver enzymes declined (ALT $80 \mathrm{IU} / \mathrm{L}$ AST $70 \mathrm{IU} / \mathrm{L}$ ) and albumin increased to $2.9 \mathrm{gr} / \mathrm{dL}$. Blood parameters returned to normal values 7 days after using the IVIG treatment. The patient was discharged on the $7^{\text {th }}$ day. The patient was asymptomatic and well on follow-up to 1 month.

\section{DISCUSSION}

The pathogenesis of DRESS syndrome is not yet well understood. Although it is considered an idiosyncratic reaction of drugs seen most commonly with anticonvulsants, reactivation of HHV-6, HHV-7, EBV, or CMV may serve as a trigger for the reaction $(8,9,10)$. In a study of 100 patients with DRESS, an increase in the antibody titer against HHV-6 was detected in approximately 60 percent of patients two to four weeks after the onset of symptoms (11). In another study including 40 pa-

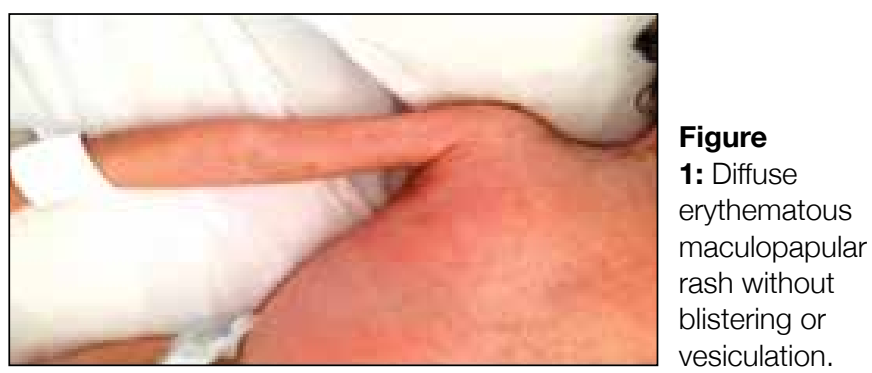

tients with DRESS, evidence of EBV, HHV-6, or HHV-7 reactivation was found in 29 patients (12). A recent study including 34 patients with DRESS reported evidence of CMV reactivations in $17.6 \%$ of the patients (13). It is still not clear whether an increase in viral load occurs in association with the development of severe drug eruptions or whether individuals with increased viral loads are at greater risk of developing severe drug eruptions. Longitudinal studies could help clarify this challenging concurrence.

A knowledge gap exists on the management of DRESS as no controlled trials have been performed to determine the efficacy of different therapies. Mild cases may be managed simply with drug withdrawal and supportive therapy. If symptoms are more severe, systemic corticosteroid therapy is indicated, usually with prednisone at a dose of 1 to $2 \mathrm{mg} / \mathrm{kg} /$ day (6).

Although steroids are recommended when involvement of internal organs is manifest, we did not consider steroid use because of the presence of CMV infection The use of IVIG in Drug Induced Hypersensitivity Syndrome (DIHS) including Toxic Epidermal Necrolysis (TEN) and Steven Johnson Syndrome (SJS) has been reported earlier (14). However, the use of IVIG in DRESS has been only anecdotal (15). In a large study of 281 patients, the management of severe cutaneous adverse reaction which included supportive care, IVIG, corticosteroids and IVIG with or without corticosteroids did not show any significant differences between the treatments (16). Some researchers suggest that IVIG should not be used as a single treatment in DRESS as they have found the persistence of multiple viral reactivations and absence of significant modification of immunologic parameters. after IVIG treatment (17).

Some researchers have suggested that IVIG might be effective in a few patients with DRESS, although these patients were concomitantly treated with systemic corticosteroids $(18,19)$. The exact mechanism of the therapeutic effect of IVIG in DRESS syndrome is not clear. The antiviral effect of IVIG has been postulated as a mechanism. Immunosuppressive agents may enhance viral reactivations. In a retrospective study of DRESS, HHV-6 and CMV viral loads were detected to be higher in patients receiving corticosteroids compared with those without corticosteroid therapy and it was suggested that the degree and duration of HHV-6 and CMV reactivation could be greatly influenced by the use of immunosuppressive drugs (13). No adverse reaction due to IVIG occurred in our case. The fever re- 
solved within two days and her laboratory values had returned to normal values by seven days. In conclusion, a diagnosis of DRESS should be considered in any patient with severe rash, fever, eosinophilia or lymphocytic changes. Cytomegalovirus may serve as a trigger for the reaction. Although treatment consists of supportive therapy, corticosteroids, and antihistamines, we achieved the desired clinical response with IVIG.

\section{REFERENCES}

1. Bocquet H, Bagot M, Roujeau JC. Drug-induced pseudolymphoma and drug hypersensitivity syndrome (Drug Rash with Eosinophilia and Systemic Symptoms: DRESS). Semin Cutan Med Surg 1996;15:250-7.

2. Husain Z, Reddy BY, Schwartz RA. DRESS syndrome: Part I. Clinical perspectives. J Am Acad Dermatol 2013; 68:693.e1.

3. Husain Z, Reddy BY, Schwartz RA. DRESS syndrome: Part II. Management and therapeutics. J Am Acad Dermatol 2013; 68:709.e1.

4. Criado PR, Criado RFJ, Avancini JM, Santi CG. Drug Reaction with Eosinophilia and Systemic Symptoms (DRESS)/Drug-Induced Hypersensitivity Syndrome (DIHS): A review of current concepts. An Bras Dermatol 2012;87:435-49.

5. Kardaun SH, Sidoroff A, Valeyrie-Allanore L, Halew S, Davidovici $\mathrm{BB}$, Mockenhaupt $\mathrm{M}$, et al. Variability in the clinical pattern of cutaneous side-effects of drugs with systemic symptoms: Does a DRESS syndrome really exist? Br J Dermatol 2007;156:609-711.

6. Cacoub P, Musette P, Descamps V, Meyer O, Speirs C, Finzi $\mathrm{L}$, et al. The DRESS syndrome: A literature review. Am J Med 2011;124:588-97.

7. Descamps V, Valance A, Edlinger C, Fillet AM, Grossin M, LebrunVignes B, et al. Association of human herpesvirus 6 infection with drug reaction with eosinophilia and systemic symptoms. Arch Dermatol 2001;137:301-4.

8. Kano Y, Hiraharas K, Sakuma K, Shiohara T. Several herpesviruses can reactivate in a severe drug-induced multiorgan reaction in the same sequential order as in graft-versus-host disease. $\mathrm{Br} J$ Dermatol 2006;155:301-6.
9. Hashizume H, Takigawa M. Drug-induced hypersensitivity syndrome associated with cytomegalovirus reactivation: Immunological characterization of pathogenic T cells. Acta Derm Venereol (Stockh) 2005;85:47-50.

10. Descamps V, Mahe E, Houhou N, Abramowitz L, Rozenberg F, Ranger Rogez S, et al. Drug-induced hypersensitivity syndrome associated with Epstein-Barr virus infection. Br J Dermatol 2003; 148:1032-34.

11. Tohyama M, Hashimoto K, Yasukawa M, Kimura H, Horikawa T, Nakajima K, et al. Association of human herpesvirus 6 reactivation with the flaring and severity of drug-induced hypersensitivity syndrome. Br J Dermatol 2007; 157:934-40.

12. Picard D, Janela B, Descamps V, D'Incan M, Courville P, Jacquot $S$, et al. Drug reaction with eosinophilia and systemic symptoms (DRESS): A multiorgan antiviral T cell response. Sci Transl Med 2010;2:46ra62.

13. Ishida T, Kano Y, Mizukawa Y, Shiohara T. The dynamics of herpesvirus reactivations during and after severe drug eruptions: Their relation to the clinical phenotype and therapeutic outcome. Allergy 2014; 69: 798-805.

14. Aihara M, Sugita Y, Takehashi, Nagatani T, Arata S, Takeuchi K, et al. Anticonvulsant hypersensitivity syndrome associated with reactivation of cytomegalovirus. Br J Dermatol 2001;144:1231-4.

15. Viard L, Wehrli P, Bullani R, Schneider P, Holler N, Salomon D, et al. Inhibition of toxic epidermal necrolysis by blockade of CD95 with intravenous immunoglobulin. Science 1998;282:490-3.

16. Fields KS, Petersen MJ, Chiao E, Tristani-Firouzi P. Nevirapineassociated dress syndrome with intravenous immunoglobulin (IVIG). J Drugs Dermatol 2005;4:510-3.

17. Schneck J, Fagot JP, Sekula P, Sassalos B, Roujeau JC, Mockhenhaupt M. Effects of treatments of the mortality of Steven Johnson syndrome and toxic epidermal necrolysis; a retrospective study on patients included in the prospective EuroSCAR study. J Am Acad Dermatol 2008;58:33-40.

18. Tas S, Simonart T. Management of drug rash with eosinophilia and systemic symptoms (DRESS SYNDROME): An update. Dermatology 2003;206:353-6.

19. Kano Y, Inaoka M, Sakuma K, Shihora T. Virus reactivation and intravenous immunoglobulin (IVIG) therapy of drug-induced hypersensitivity syndrome. Toxicology 2005;209:165-7. 